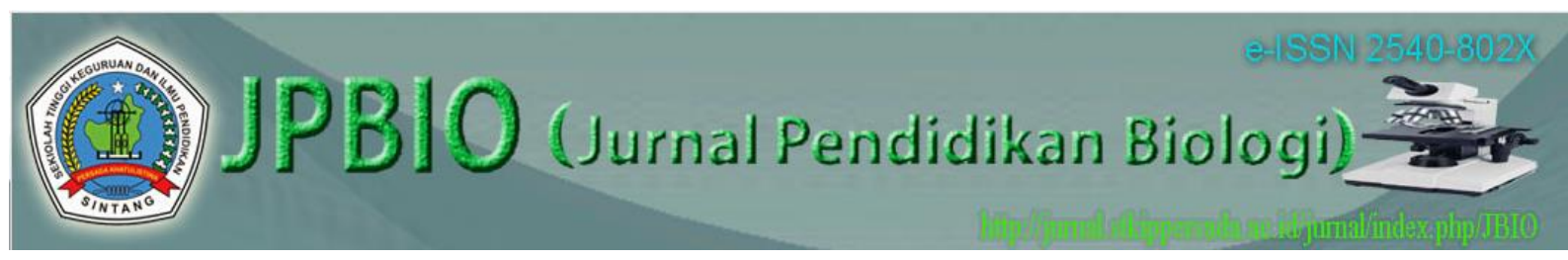

JPBIO (Jurnal Pendidikan Biologi)

Vol. 2 No. 1, April 2017 | $18-25$

ISSN 2540-802x (Online)

DOI: http://dx.doi.org/10.31932/ JPBIO (Jurnal Pendidikan Biologi)

http://jurnal.stkippersada.ac.id/jurnal/index.php/JBIO

\title{
PENGARUH MODEL PEMBELAJARAN QUANTUM TEACHING BERMEDIA PETA TIMBUL TERHADAP HASIL BELAJAR KOGNITIF PADA MATERI SISTEM GERAK MANUSIA DI KELAS VIII SMP NEGERI 2 MENUKUNG TAHUN PELAJARAN 2016/2017
}

\author{
Yohana Eka Mawarni ${ }^{{ }^{\star}}$, Hilarius Jago Duda ${ }^{2}$
}

${ }^{1}$ Mahasiswa Program Studi Pendidikan Biologi, STKIP Persada Khatulistiwa Sintang

${ }^{1}$ Dosen Program Studi Pendidikan Biologi, STKIP Persada Khatulistiwa Sintang

email:Yohanna555@yahoo.com*, hilariusjagod@yahoo.com

Diterima: 20 Februari 2017

Direvisi: 07 Maret 2017

Disetujui: 28 Maret 2017

\begin{abstract}
ABSTRAK
Penelitian ini bertujuan untuk mengetahui penerapan model pembelajaran Quantum Teaching bermedia peta timbul terhadap hasil belajar kognitif siswa pada materi sistem gerak manusia. Pendekatan penelitian yang diterapkan dalam penelitian ini adalah pendekatan kuantitatif. Metode penelitian ini adalah penelitian eksperimen. Bentuk penelitian ini adalah Quasi Experimental dengan menggunakan Nonequivalent Control Group Design. Populasi dalam penelitian ini adalah seluruh siswa kelas VIII Sekolah Menegah Pertama Negeri 2 Menukung yang berjumlah 42 siswa. Sampel dalam penelitian adalah kelas VIIIA sebagai kelas eksperimen dengan jumlah siswa 21 orang dan kelas VIIIB sebagai kelas kontrol dengan jumlah siswa 21 orang. Teknik sampling yang digunakan adalah Sampling Jenuh. Alat pengumpulan data yang digunakan adalah, soal tes. Berdasarkan analisis data diperoleh hasil penelitian sebagai berikut: Hasil belajar kognitifrata-rata siswa setelah menggunakan model Quantum Teaching adalah 0,73 dengan kriteria tinggi, sedangkan hasil belajar kognitif rata-rata siswa setelah menggunakan metode konvensional adalah 0,23 kriteria rendah. Berdasarkan uji hipotesis pada posttest kelas eksperimen dan kelas kontrol diperoleh $t$ hitung sebesar 6,12 dan $t$ tabel sebesar 2,02108. Pengujian hipotesis membuktikan bahwa $\mathrm{t}$ hitung $>\mathrm{t}$ tabel $(6,12>2,02108)$ yang artinya Ha diterima dan $\mathrm{Ho}$ ditolak. Hal ini menunjukkan bahwa terdapat perbedaan yang signifikan hasil belajar kognitif siswa pada materi sistem gerak manusia antara kelas eksperimen dan kelas kontrol.
\end{abstract}

Kata Kunci: model quantum teaching, peta timbul, dan hasil belajar kognitif

\section{ABSTRACT}

This study aims to determine the application of learning models Quantum Teaching assisted map ensue for the cognitive achievement of students on the material system of human motion. The method applied in this research is quantitative method. Forms of this study is an experimental research.The research design was Quasi Experimental Design using 
Nonequivalent Control Group Design. The population in this study were all students of class VIII SMP Negeri 2 Menukung totaling 42 students.Samples are VIIIA class as a class experiment with the number of students 21 and VIIIB class as a class controls the number of students 21 people. The sampling technique used is saturated sampling. The data collection technique used is the technique of direct observation, measurement techniques, and techniques of indirect communication. Data collection tools used were observation sheet, test questions, and the sheet student questionnaire responses. Based on the analysis of data obtained the following results:The results of the experimental observation grade students gained an average of the first and second meeting of $92.20 \%$ with a very strong criteria, whereas the observation of control class gained an average of the first and second meeting of $57.64 \%$ with a sufficient criterion. The results of the experimental class teacher observation gained an average of the first and second meetings of $100 \%$ with good criteria, while the results of the control class teacher observation gained an average of the first and second meetings of $100 \%$ with good criterion. Average learning outcomes of students after using the model of Quantum Teaching is 0.73 with a high criteria, while the average learning outcomes of students after using the conventional method is 0.23 low criteria. Based on the hypothesis test posttest experimental class and control class obtained t count equal to 19.87 and $t$ table of 2.02108. Testing the hypothesis proves that $t$ acount $t$ table $(6,12>2.02108)$, which means $\mathrm{Ha}$ accepted and Ho rejected. This shows that there are significant differences cognitive achievement of students on the material system of human movement between the experimental class and control class. Students' response to the application of Quantum Teaching learning model obtained a total percentage score of $84.88 \%$ with a very strong criteria.

Keywords: quantum teaching model, map arise, and cognitive learning outcomes

\section{PENDAHULUAN}

Menurut Trianto, (2009: 4) "Pada abad ke-21, sistem pendidikan nasional menghadapi tantangan yang sangat kompleks dalam menyiapkan kualitas sumber daya manusia (SDM) yang mampu bersaing di era global. Upaya yang tepat untuk menyiapkan sumber daya manusia (SDM) yang berkualitas dan satu-satunya wadah yang dapat dipandang dan berfungsi sebagai alat untuk membangun sumber daya manusia (SDM) yang bermutu tinggi adalah pendidikan.

Menurut Rusman, (2010: 230) "pendidikan bukan hanya menyiapkan masa depan, tetapi juga bagaimana menciptakan masa depan". Dalam hal ini pendidikan harus mampu mengembangkan potensi peserta didik, membentuk individu yang kritis dengan keterampilan berpikir yang tinggi sehingga yang bersangkutan mampu menghadapi dan memecahkan problema kehidupan yang dihadapinya. Kenyataan yang terjadi, hingga saat ini dunia pendidikan kita masih tidak lepas dari permasalahan. Permasalahan yang kerap kali dihadapi adalah kualitas hasil pendidikan disegenap jenjang dan jalur pendidikan yang masih belum memuaskan, hal ini terjadi salah satunya karena masih lemahnya proses pembelajaran dan model pembelajaran yang guru gunakan kerap kali kurang menarik minat belajar siswa. Pembelajaran merupakan bagian atau elemen yang memiliki peran sangat dominan untuk menunjukkan kualitas dalam upaya menghasilkan peserta didik yang kreaktif. Pembelajaran juga memiliki pengaruh yang menyebabkan rendahnya kualitas pendidikan. Pendidikan merupakan salah satu jalur yang sangat penting dan strategis untuk meningkatkan sumber daya manusia yang bermutu. Proses belajar-mengajar dalam dunia pendidikan untuk mencapai sumber daya manusia bermutu dapat dicapai melalui berbagai model pembelajaran sebagai daya tarik bagi siswa untuk belajar.

Adapun faktor-faktor yang mempengaruhi terhadap permasalahan diatas yaitu cara mengajar guru yang didominasi dengan ceramah membuat siswa menjadi kurang aktif dan kurang merasa tertarik, sehingga siswa merasa tidak bertanggung jawab saat pembelajaran 
berlangsung dan hanya bergantung penuh kepada guru menyebabkan siswa kurang untuk bertanya dan membuat suasana pembelajaran menjadi tidak efektif. Permasalahan lain yang mempengaruhi adalahpenggunaan model pembelajaran konvensional, membuat siswa menjadi pasif, cepat lelah, merasa kurang tertarik, bosan, dan cepat mengantuk.

Menurut para guru dan yang lebih khususnya guru mata pelajaran IPA Terpadu permasalahan yang menyebabkan hasil belajar siswa tidak tuntas yaitu latar belakang dari setiap siswa serta minat belajar yang kurang di dominasi dari diri sendiri dan faktor lainnya yaitu pada saat mengajar guru kurang menggunakan fasilitasmedia pada saat mengajar dikarenakan kurang tersedianya dana, pemecahan kasus yang tidak tuntas, listrik yang kurang mendukung jika harus menggunakan infokus, dan kurangnya sumber-sumber pembelajaran karena biaya yang tidak mencukupi.

Hal ini menjadi permasalahan bagi guru dalam membangkitkan minat belajar siswa, motivasi belajar, keaktifan siswa, prestasi siwa yang akan mempengaruhi hasil belajar siswa.Mengatasi permasalahan tersebut, diperlukan pemilihan model pembelajaran dan media belajar yang tepat serta perangkat pembelajaran yang lengkap termasuk silabus dan RPP. Pada penelitian ini peneliti menggunakan media peta timbul. Media peta timbul termasuk media visual yang penyajiannya secara visual tiga dimensi yang ditempelkan gambar rangka sistem gerak manusia diatas steliofrom dan dibuat sendiri oleh penulis. Penulis memberikan solusi model pembelajaran Quantum Teaching bermedia petatimbul supaya suasana belajar lebih aktif dan dengan adanya media peta timbul dapat memberikan motivasi baru bagi siswa, aktif dan kreatif untuk mendapatkan hasil belajar kognitif yang tuntas bagi siswa itu sendiri dalam pembelajaran biologi materi sistem gerak manusia. Penulis berharap dengan menerapkan model pembelajaran Quantum Teaching bermedia peta timbul diharapkan dapat meningkatkan kognitif siswa.

Masalah dalam penelitian ini adalah "Bagaimanakah pengaruh model pembelajaran Quantum Teaching bermedia peta timbul terhadap hasil belajar kognitif pada materi sistem gerak manusia di kelas VIII Sekolah Menengah Pertama Negeri 2 Menukung Tahun Ajaran 2016/2017?" Berdasarkan uraian rumusan masalah di atas, maka tujuan dari penelitian ini adalah untuk mengetahui pengaruh model Quantum Teaching bermedia peta timbul terhadap hasil belajar kognitif pada materi sistem gerak manusia di kelas VIII Sekolah Menengah Pertama Negeri 2 Menukung Tahun Ajaran 2016/2017.

\section{METODE PENELITIAN}

Penelitian ini dilaksanakan pada siswa kelas VIII SMP Negeri 2 Menukung dengan tujuan untuk mengetahui perbedaan yang signifikan hasil belajar kognitif antara siswa yang menggunakan Model PembelajaranQuantum Teaching Bermedia peta timbul dengan siswa yang menggunakan metode konvensional. Jenis pendekatan penelitian yang digunakan yaitu pendekatan kuantitatif. Metode penelitian yang digunakan dalam penelitian ini adalah Eksperiment.Desain penelitian ini menggunakan nonequivalent control group desaign (Sugiyono, 2012:79). Rancangan ini dipilih karena eksperimen dilakukan di kelas tertentu dengan kelas yang telah ada. Dalam menentukan subyek untuk kelompok eksperimen maupun kelompok kontrol tidak memungkinkan mengubah kelas yang telah ada. Dengan demikian randomisasi tidak bisa dilakukan. Dalam menetapkan kelompok eksperimen dan kelompok kontrol dilakukan secara acak terhadap kelas yang ada. Dalam penelitian ini data yang digunakan adalah data hasil tes siswa. Untuk mengumpulkan data tersebut digunakan instrumen tes hasil belajar, yaitu tes untuk mengukur hasil belajar kognitif siswa.

Populasi penelitian ini adalah seluruh siswa-siswa kelas VIII SMP Negeri 2 Menukung. Banyaknya anggota populasi dalam penelitian adalah 42 orang siswa yang terbagi menjadi 2 kelas, yaitu VIIIA 21 dan VIIIB 21. Untuk menguji kesetaraan diantara kedua sampel tersebut, terlebih dulu dilakukan analisis uji prasyarat terhadap hasil belajar kognitif siswa kelas VIII yang diambil melalui hasil pre test. Setelah menguji nilai pre test IPA siswa kelas 
VIII yang diperoleh dari dua kelas, yaitu kelas VIIIA dan VIIIB SMP Negeri 2Menukung dengan menggunakan uji normalitas dan uji homogenitas. Hasil uji instrumen terhadap 40 soal yang telah dilakukan, yaitu uji validitas, reliabilitas, tingkat kesukaran dan daya pembeda diperoleh 20 soal yang digunakan sebagai soal pretest dan post-test. Data hasil belajar yang diperoleh dari hasil post test kemudian dianalisis dengan uji-t untuk uji hipotesis, namun sebelum uji hipotesis dilakukan uji prasyarat, yang meliputi uji normalitas dan uji homogenitas varians. Setelah uji prasyarat dan data hasil belajar yang diperoleh berdistribusi normal dan homogen dilanjutkan dengan uji hipotesis yaitu dengan menggunakan analisis data yaitu uji t-test satu sampel dan uji t dua sampel.

\section{HASIL DAN PEMBAHASAN}

Adapun deskripsi data hasil penelitian dari kelompok eksperimen dan kelompok kontrol adalah sebagai beikut. Kelas VIIIA yang menjadi kelompok eksperimen menerapkan model Quantum Teaching bermedia peta timbul. Data hasil belajar kognitif yang menjawab soal pretest nilai tertinggi yang dicapai siswa 50 dan nilai terendah yang dicapai siswa 15 . Soal post test terdiri dari nilai tertinggi yang dicapai siswa yaitu 95 dan nilai terendah yang dicapai siswa yaitu 60. Kelas VIIIB yang menjadi kelompok kontrol menerapkan metode pembelajaran konvensional. Data hasil belajar kognitif siswa yang menjawab soal pretest nilai tertinggi yang dicapai siswa 65 dan nilai terendah yang dicapai siswa 30. Soal post test terdiri dari nilai tertinggi yang dicapai siswa yaitu 80 dan nilai terendah yang dicapai siswa yaitu 45.Analisis nilai pretes dan posttest kelas eksperimen dan kelas kontrol disajikan pada Tabel 1 dan Tabel 2.

Tabel 1 Nilai Hasil Belajar Kognitif Siswa kelas Eksperimen

\begin{tabular}{cccccc}
\hline Kelas & \multicolumn{2}{c}{ Nilai } & Nilai rata-rata & Jumlah siswa & Keterangan \\
\cline { 2 - 3 } pretest & 50 & & & & \\
posttest & 95 & 60 & 81,90 & 21 & Rendah \\
\hline
\end{tabular}

Tabel 2 Nilai Hasil Belajar Kognitif Siswa kelas Kontrol

\begin{tabular}{cccccc}
\hline Kelas & \multicolumn{2}{c}{ Nilai } & Nilai rata-rata & Jumlah siswa & Keterangan \\
\cline { 2 - 3 } pretest & Tertinggi & Terendah & & & \\
posttest & 65 & 30 & 50,95 & 21 & Rendah \\
\hline
\end{tabular}

Setelah mendapatkan data hasil belajar kognitif tersebut selanjutnya dilakukan uji prasyarat yaitu uji normalitas dan uji homogenitas sebelum dilanjutkan dianalisis dengan ujit. Hasil uji analisis data kelas eksperimen pretest diperoleh $x 2 h i t=7,46$ sedangkan untuk taraf signifikan $5 \%(\alpha=0,95)$ dan derajat kebebasan $(\mathrm{db})=20$ diperoleh $\times 2$ tabel $=11,07$, karena $x 2 h i t<x 2 t a b e l$, ini berarti sebaran data nilai akhir kelompok eksperimen berdistribusi normal. Sedangkan uji normalitas data pretest kelompok kontrol diperoleh $x 2 h i t=4,84$ sedangkan untuk taraf signifikan $5 \%(\alpha=0,95)$ dan derajat kebebasan $(\mathrm{db})=20$ diperoleh $x 2$ tabel $=11,07$. karena $x 2 h i t<x 2$ tabel, ini berarti sebaran data nilai akhir kelompok kontrol berdistribusi normal. Hasil uji analisis data kelas eksperimen posttest diperoleh $x 2 h i t=8,25$ sedangkan untuk taraf signifikan $5 \%(\alpha=0,95)$ dan derajat kebebasan $(\mathrm{db})=20$ diperoleh $x$ 2tabel $=11,07$, karena $x 2 h i t<x 2$ tabel , ini berarti sebaran data nilai akhir kelompok eksperimen berdistribusi normal. Sedangkan uji normalitas data posttest kelompok kontrol diperoleh $\times 2 h i t=6,49$ sedangkan untuk taraf signifikan $5 \%(\alpha=0,95)$ dan derajat kebebasan $(\mathrm{db})=20$ diperoleh $x 2$ tabel $=11,07$. karena $x 2$ hit $<x 2$ tabel, ini berarti sebaran data nilai akhir kelompok kontrol berdistribusi normal. Analisis uji normalitas nilai pretes dan posttest kelas eksperimen dan kelas disajikan pada Tabel 3. 
Tabel 3 Hasil uji normalitas data pretest dan posttest kelas eksperimen dan kelas kontrol

\begin{tabular}{cccccc}
\hline Data yang diuji & $\overline{\boldsymbol{X}}$ & $\mathbf{X}^{2}$ hitung & $\mathbf{X}^{2}$ tabel & Alpha & Keterangan \\
\hline Pretest Eksperimen & 31,78 & 7,46 & 11,07 & $5 \%$ & Normal \\
$\begin{array}{c}\text { Pretest Kontrol } \\
\text { Posttest }\end{array}$ & 51,11 & 4,84 & 11,07 & $5 \%$ & Normal \\
$\begin{array}{c}\text { Eksperimen } \\
\text { Posttest Kontrol }\end{array}$ & 61,92 & 8,25 & 11,07 & $5 \%$ & Normal \\
\hline
\end{tabular}

Sumber: Data Olahan 2016

Uji homogenitas data pretest menunjukkan $F$ hitung sebesar 1,26 sedangkan $F$ tabel pada taraf signifikansi $5 \%$ dengan $\mathrm{db}$ pembilang $=20$ dan $\mathrm{db}$ penyebut $=20$ adalah 2,12. Data posttest menunjukkan $F$ hitung sebesar 1,05 sedangkan $F$ table 2,12 pada taraf signifikan $5 \%$ dengan db pembilang=20 dan db penyebut=20. Ini berarti Fhitung < Ftabel maka data nilai akhir kelompok eksperimen dan nilai akhir kelompok kontrol adalah homogen. Analisis uji homogenitas pretes dan posttest kelas eksperimen dan kelas disajikan pada Tabel 4 dan Tabel 5.

Tabel 4 Hasil uji homogenitas pretest siswa kelas eksperimen dan kelas kontrol

\begin{tabular}{cccccc}
\hline No & Data yang Diuji & $\mathrm{A}$ & $\mathrm{F}_{\text {hitung }}$ & $\mathrm{F}_{\text {tabel }}$ & Ket \\
\hline $\mathbf{1}$ & Pretest Eksperimen & 0,05 & 1,26 & 2,12 & Homogen \\
$\mathbf{2}$ & Pretest Kontrol & & & & \\
\hline
\end{tabular}

Tabel 5 Hasil uji homogenitas posttest siswa kelas eksperimen dan kelas kontrol

\begin{tabular}{cccccc}
\hline No & Data yang Diuji & $\alpha$ & $\mathrm{F}_{\text {hitung }}$ & $\mathrm{F}_{\text {tabel }}$ & Ket \\
\hline $\mathbf{1}$ & Posttest Eksperimen & 0,05 & 1,05 & 2,12 & Homogen \\
$\mathbf{2}$ & Posttest Kontrol & & & & \\
\hline
\end{tabular}

Hasil perhitungan uji prasyarat diperoleh hasil bahwa data nilai hasil belajar kognitif kelompok eksperimen dan kelompok kontrol berada dalam keadaan normal dan homogen. Oleh karena itu dilakukan uji hipotesis. Hipotesis penelitian dapat dirumuskan sebagai berikut : $\mathrm{Ha}: \mu 1 \neq \mu 2$. Terdapat perbedaan yang signifikan hasil belajar kognitif siswa antara kelas eksperimen yang menggunakan model pembelajaran Quantum Teaching dan kelas kontrol yang menggunakan metode konvensional pada materi sistem gerak manusia di kelas VIII Sekolah Menengah Pertama Negeri 2 Menukung. $\mathrm{H} 0: \mu 1=$ $\mu 2$. Tidak terdapat perbedaan yang signifikan hasil belajar kognitif siswa antara kelas eksperimen yang menggunakan model pembelajaran Quantum Teaching dan kelas kontrol yang menggunakan metode konvensional pada materi sistem gerak manusia di kelas VIII Sekolah Menengah Pertama Negeri 2 Menukung.Berdasarkan hasil analisis data diperoleh t hitung sebesar 6,12. Dengan taraf signifikansi $5 \%$ dan $\mathrm{dk}=40$ diperoleh batas penolakan hipotesis nol sebesar 2,02108. Berarti t hitung $>t$ tabel, maka hipotesis nol yang diajukan ditolak dan menerima hipotesis alternatif. Analisis uji hipotesis dapat dilihat pada Tabel 6. 
Tabel 6 Hasil uji hipotesis uji t dua sampel kelas eksperimen dan kontrol

\begin{tabular}{cccccc}
\hline Kelas & $\mathrm{N}$ & Rerata Posttest & $\mathrm{t}_{\text {hitung }}$ & $\mathrm{t}_{\text {tabel }}$ & Keterangan \\
\hline VIIIA (Kelas & 2 & 81,66 & 6,12 & 2,02108 & Ha diterima dan $\mathrm{H}_{0}$ \\
Eksperimen) & 1 & & & & ditolak \\
VIIIB (Kelas Kontrol) & 2 & 62,38 & & & \\
& 1 & & & & \\
\hline
\end{tabular}

Dapat dinyatakan bahwa terdapat perbedaan yang signifikan hasil belajar kognitif siswa antara kelas eksperimen yang menggunakan model pembelajaran Quantum Teaching dan kelas kontrol yang menggunakan metode konvensional pada materi sistem gerak manusia di kelas VIII Sekolah Menengah Pertama Negeri 2 Menukung.Model Quantum Teaching mengajak siswa belajar dalam suasana yang lebih nyaman dan menyenangkan, sehingga siswa menjadi lebih aktif dalam menemukan berbagai pengalaman baru dalam belajarnya. Quantum Teaching juga membuat hubungan yang dinamis dalam lingkungan belajar sehingga terjalin interaksi yang menjadikan landasan untuk belajar (De porter. B, 2004). DePorter mengungkapkan bahwa "penerapan model pembelajaran Quantum Teaching bermedia peta timbul dalam pembelajaran dapat menggabungkan keistimewaan- keistimewaan belajar menuju bentuk perencanaan pengajaran yang melejitkan prestasi siswa" (DePorter,dkk.2009:3).

\section{SIMPULAN}

Adapun kesimpulan yang dapat disampaikan setelah melaksanakan dan memperoleh hasil dari penelitian yaitu:(1) Dari penghitungan uji t- satu sampel pada kelas eksperimen diperoleh t hitung $>\mathrm{t}$ table $(22,02>2,02108)$. Hipotesisnya Ho ditolak dan $\mathrm{Ha}$ diterima yang artinya terdapat perbedaan yang signifikan hasil belajar kognitif siswa pada kelas eksperimen pada pengukuran awal da pengukuran akhir. (2) Dari penghitungan uji $\mathrm{t}$ - satu sampel pada kelas kontrol diperoleh $\mathrm{t}$ hitung $>\mathrm{t}$ table $(4,92>2,02108)$. Hipotesisnya Ho ditolak dan Ha diterima yang artinya terdapat perbedaan yang signifikan hasil belajar kognitif siswa pada kelas kontrol pada pengukuran awal da pengukuran akhir. (3)Dari penghitungan uji t- Dua sampel pada kelas kontrol diperoleh $t$ hitung $>t$ table $(6,12>2,02108)$. Hipotesisnya Ho ditolak dan Ha diterima yang artinya terdapat perbedaan yang signifikan hasil belajar kognitif siswa antra kelas eksperimen yang menggunakan model pembelajaran Quantum Teaching dengan kelas kontrol yang menggunakan metode konvensional pada materi sistem gerak manusia di kelas VIII Sekolah Menengah Pertama Negeri 2 Menukung. Adapun saran yang dapat disampaikan setelah melaksanakan dan memperoleh hasil dari penelitian yaitu (1) Guru dapat mencoba menggunakan model yang tepat dalam proses pembelajaran, sehingga siswa tidak merasa jenuh dan bosan (2) perlu adanya penelitian lanjutan dengan model pembelajaran Quantum Teaching pad materi yang lain.

\section{REFERENSI}

Adhani, H. (2014). "Penerapan Metode Pembelajaran TANDUR Terhadap Kemampuan Berfikir Kritis Siswa pada Materi Pencemaran dan Kerusakan Lingkungan Dikelas VII Sekolah Menengah Pertama Negeri 4 Sintang".Skripsi tidak diterbitkan. Sintang: STKIPPersada Khatulistiwa.

Arikunto, S. (2002). Prosedur Penelitian Suatu Pendekatan Praktek. Jakarta: Rineka Cipta. 
Arikunto. (2013). Prosedur penelitian suatu pendekatan praktik /suharsimi arikunto. Jakarta :Rineka cipta.

Aristo. (2016). "Pengaruh model pembelajaran active learning terhadap kemampuan berpikir kreatif siswa pada materi sistem pernapasan manusia kelas VIII SMP Negeri 2 Sintang Tahun Pelajaran 2015/2016".Skripsi tidak diterbitkan Sintang: STKIP Sintang Persada Khatulistiwa Sintang.

Azhar, M.A. (2013). Media pembelajaran. Jakarta : Alfabeta

Danang W. Nym. Jampel. Md. Sumantri. (2014). "Penerapan Model Pembelajaran Kuantum (Quantum Teaching) Untuk Meningkatkan Aktivitas Dan HasilBelajar Matematika Pada Siswa Kelas III SD No. 1 Jinengdalem". Journal Mimbar PGSD Universitas Pendidikan Ganesha, 2(1), 1 -10.

Daryanto. (2013). Media Pembelajaran Perannya Sangat Penting Dalam Mencapai Tujuan Pembelajaran. Yogyakarta :Gava Media.

Dimyati, M. (2006). Belajar dan Pembelajaran. Jakarata: Rineka Cipta.

Henry, Kuswanto ,dan Hartinigsih, T. (2009). IPA Terpadu Untuk SMP/MTs kelas VIII. Jakarta: Sahabat.

Herlina W. (2014). "Pengaruh Model Pembelajaran Quantum Teaching Terhadap Minat Dan Hasil Belajar Ipa Siswa Kelas IvGugus XIII Kecamatan Buleleng”. Journal Mimbar PGSD Universitas Pendidikan Ganesha, 2(1), 1-10.

Jumiyanto, D. (2012). Penggunaan Metode Pembelajaran Quantum Teaching Untuk Meningkatkan Motivasi Belajar dan Prestasi belajar Siswa Mata Diklat Gambar Teknik Di Smk Perindustrian Yogyakarta. Skripsi di Fakultas Teknik Universitas Negeri Yogyakarta. (Online) tersedia di: (http://eprints.uny.ac.id/6687/1/Skripsi Danang\%20Jumiyanto.pdf, diakses 14 Januari 2015)

Julka. (2015). "Pengaruh model pembelajaran talking stick dengan media interaktif dalam meningkatkan hasil belajar kognitif siswa pada materi ciri-ciri makhluk hidup Sekolah Menengah Pertama Negeri 02 Menukung". Skripsi tidak diterbitkan. Sintang: STKIP Sintang Persada Khatulistiwa Sintang.

Ketut Suparta. Siti Zulaikha. Gede Meter. (2014). "Penerapan Model Pembelajaran Quantum Untuk Meningkatkan Motivasi Dan Hasil Belajar Ipa Siswa Kelas VI SD Fajar Harapan Kuta Utara Badung". e-Journal Mimbar PGSD Universitas Pendidikan Ganesha, 2 (1) 1-11.

Kementerian Pendidikan Nasional. (2010). Pengembangan Pendidikan Budaya dan Karakter Bangsa.

Kuswan. (2012). Taksonomi kognitif perkembangan ragam berpikir. Bandung:PT Remaja Rosdakarya. 
Kusrini. (2015). "Efektivitas Model Cooperatif Learning Tipe Teams Games Tournament terhadap Kemampuan Berfikir Kritis dan Hasil Belajar Siswa Kelas XI MIA pada Pokok Bahasan Sel". Skripsi tidak diterbitkan. Sintang: STKIP Persada Khatulistiwa.

Lova, E.M. (2014). "Penerapan Model Quantum Teaching Terhadap Hasil Belajar Siswa pada Materi Protista Dikelas X SMAN 4 Sintang”. Skripsi tidak diterbitkan. Sintang: STKIP Persada Khatulistiwa.

Miffahul, A'La. (2012). Quantum Teaching (Buku Pintar dan Praktis). jogjakarta: Diva Press.

Paramitasari, D. (2014). Penerapan Model Pembelajaran Quantum Teachingterhadap kemampuan kognitif belajar siswa pada materi sistem peredaran darah manusia di kealas VIII SMPN 5 Dedai Tahun Pelajaran 2014/2015". Skripsi tidak diterbitkan.. Sintang: STKIP Persada Khatulistiwa.

Purwanto, N.(2009). Prinsip-prinsip dan Teknik Evaluasi Pengajaran. Bandung: Remaja Rosda Karya

Riani, C. (2013). "Pengaruh Model Pembelajaran Quantum Teaching Terhadap Hasil Belajar kognitif Siswa pada Materi Sistem Gerak Manusia Kelas VIIIB SMP 1 Kealam Permai". Skripsi tidak diterbitkan. Sintang: STKIPPersada Khatulistiwa.

Rusman. (2013). Belajar dan Pembelajaran Bebasis Komputer. Bandung: Alfabeta.

Sudjana, N. (2009). Penilaian Hasil Proses Belajar Mengajar. Bandung: Remaja Rosdakarya.

Sugiyono. (2012). Statistik untuk penelitian . Bandung :Alfabeta

Sugiyono. (2013). Metode Penelitian Pendidikan ( Pendekatan Kuantitatif, Kualitatif, dan $R \& D)$. Bandung : Alfabeta.

Supardianningsih, Teo. S, Anis, D. R. (2014). Ilmu Pengetahuan Alam. Klaten: Intan Pariwara.

Trianto. (2009). Mendesain Model Pembelajaran Inovatif Progresif. Jakarta: Kencana.

Trianto. (2010). Model-model pembelajaran inovatif berorentasi konstruktivistik. Jakarta : Remaja Rosdakarya.

Wowo Sunaryo. (2012). Taksonomi Kognitif Perkembangan Ragam Berpikir. Bandung: PT Remaja Rosdakarya.

Yuliati, D., Sumantri, M., dan Margunayasa, G. (2014). Pengaruh Model Quantum Teaching and Learning dengan Pemanfaatan Media Gambar Terhadap Hasil Belajar IPA Siswa Kelas V SD Negeri di Gugus XI Kecamatan Beleleng". Jurnal Mimbar PGSD Universitas Pendidikan Genesha, 2(1), 1-11. 